\title{
NUMERICAL ANALYSIS OF PLAIN AND STEEL FIBER REINFORCED CONCRETE FILLED STEEL TUBULAR SLENDER COLUMN
}

\author{
Kingsley U. Ukanwa ${ }^{1, *}$, Charles G. Clifton ${ }^{1}$, James B.P. Lim ${ }^{1}$, \\ Stephen Hicks ${ }^{2}$ and Umesh K. Sharma ${ }^{3}$ \\ ${ }^{1}$ Department of Civil Engineering, The University of Auckland,Auckland, New Zealand \\ ${ }^{2}$ New Zealand Heavy Engineering Research Association, HERA House, Auckland, New Zealand \\ ${ }^{3}$ Department of Civil Engineering, India Institute of Technology, Roorkee, India \\ *(Corresponding author: E-mail: kuka298@aucklanduni.ac.nz)
}

Received: 8 August 2016; Revised: 20 April 2017; Accepted: 14 May 2017

\begin{abstract}
Concrete filled steel tube columns (CFST) have many potentials which include; high seismic resistance, high load bearing capacity, and fire resistance without external protection. Some major projects worldwide has adopted the use of this type of column member extensively, for columns in both the gravity systems and the seismic resisting systems. Experimental tests performed on concrete filled steel tube columns at ambient temperature indicates that, the use of steel fibre reinforced concrete infill affects the crack width propagation of the concrete. This paper presents an advanced 3D numerical model which predicts the behaviour of a CFST column filled with steel fibre reinforced concrete, taking into account the increased tensile strength of the concrete which affects the column ductility. For columns subjected to compression loading only, it is recommended to use a high strength concrete, and also increase the thickness of the steel tube rather than using a steel tube with a higher yield strength. For slender square columns loaded under large eccentricity, it is recommended to use an e/D (eccentricity/depth) ratio value less than 0.5 for design purposes, to avoid the premature fracture of the loaded end of the column having smaller steel tube thickness.
\end{abstract}

Keywords: Concrete filled tubular columns, steel fibre reinforced concrete, finite element analysis, composite column, square hollow steel section

DOI: $10.18057 /$ IJASC.2018.4.2.10

\section{INTRODUCTION}

Concrete filled steel tube (CFST) columns are an increasingly popular form of construction. The advantages of CFST include a high compression strength, good ductility, reduction in size of the column, ease of construction and potential fire resistance ratings (Zhao et al. [1]). The 1995 Kobe earthquake in Japan influenced the emphasis on CFST construction whereby, emphasis was placed on ductility, energy absorption and performance in seismic zones (Kitada [2]).

Steel tube local buckling is one of the critical issues to consider when designing a steel tube column. Researchers have indicated that addition of a concrete infill to the steel tube will reduce the effects of local buckling (Brauns [3], Ellobody, Young and Lam [4]). Steel fiber reinforced concrete infill is a popular type of concrete infill due to the advantages of increasing the tensile strength of the concrete and controlling the crack width of the concrete core (Ellobody [5], Zhao et al. [6]). Comprehensive experimental and numerical experiments conducted by (Zeghiche and Chaoui [7]) together with (Johansson and Gylltoft [8]), showed that it is possible to achieve ductility in the column by also using concrete strength higher than $50 \mathrm{MPa}$.

Ellobody [5], showed that addition of fiber to plain concrete increases its flexural and tensile strength, which results in superior post-elastic material properties. The various parameters that affect the behaviour of steel fiber reinforced concretes which includes its matrix strength, fiber type, fiber Young's modulus, fiber dosage and fiber tensile strength. Figure 1 shows a comparison between the stress - strain curve of plain and steel fiber reinforced concrete. 


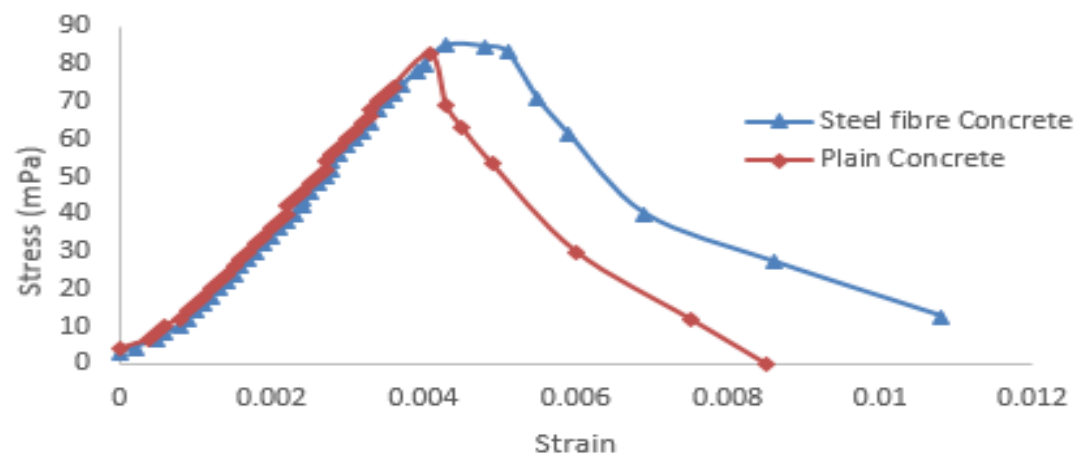

Figure 1. Comparison of Stress-strain Curves of Plain and SFR Concrete

Eltobgy [9], observed that the use of steel fibre reinforced concrete improved the structural stability of a CFST columns and the slenderness ratio is also an important factor that govern its behaviour.

Gopal and Manoharan [10], carried out tests on 12 slender circular steel tubular columns filled with both plain and steel fiber reinforced concrete. The specimens were tested under eccentric axial loading to investigate the effects of fiber reinforced concrete on the ultimate strength and behaviour of the composite columns. It was reported that the use of fiber reinforced concrete as infill for tubular steel gives the column additional strength and ductility.

Tokgoz and Dundar [11], conducted experimental tests on 16 concrete filled steel tubular columns, each tubular column was filled with either plain or steel fibre reinforced concrete. The columns were loaded axially with different levels of eccentricity having an e/D ratio between 0.5-0.67 where $\mathrm{e}$ is the eccentricity and $\mathrm{D}$ is the depth or height of the column. It was reported that the inclusion of steel fiber to the concrete improved the ductility and deformation of the column. The steel fibres, however, had little effect on the ultimate strength capacity of the column.

The main objective of the study reported herein is to investigate numerically the behaviour of axially loaded steel fiber reinforced CFST column. The numerical model is validated by comparison with experimental data reported in the literature, and also the Eurocode 4 part 1-1 [12] design model. Sixteen composite columns were simulated from experimental tests carried out by Tokgoz and Dundar [11] from the literature and the main variables for the columns were the cross-section, slenderness, concrete compressive strength and the load eccentricity. The ultimate strength and load-deflection profile of the columns were analysed and compared to the experimental results. A parametric study was also carried out to investigate the influence of the steel yield strength, steel tube thickness and concrete compressive strength to the ultimate strength and ductility of the column.

\section{FINITE ELEMENT MODELLING}

\subsection{General}

To analyse the behaviour of plain and steel fiber reinforced CFST column, A three dimensional non-linear finite element CFST column was modelled using ABAQUS [13]. 
A total of 38 CFST columns were modelled; 16 of these columns were from the literature which was used to validate the numerical simulation. The remaining 22 were used for the parametric studies. All the columns were of length of $1250 \mathrm{~mm}$ which had similar length with the experimental study. The material properties and geometry of the columns are summarized in Table 1(a) and (b). The slenderness $(\lambda)$, concrete cylindrical compressive strength $\left(f_{c}\right)$, steel yield strength and ultimate tensile strength (fy $\&$ fu) and steel ratio $(\delta)$ are also shown.

Table 1a. ABAQUS CFST Column Model for Validating Experimental Study

\begin{tabular}{|c|c|c|c|c|c|c|c|c|c|c|c|}
\hline $\mathrm{S} / \mathrm{N}$ & B $\underset{\text { mm }}{ }$ D $x$ t & $\mathrm{B} / \mathrm{t}$ & $\mathrm{e} / \mathrm{D}$ & $\mathrm{L} / \mathrm{D}$ & $\begin{array}{c}\mathrm{ex}_{\mathrm{X}} \\
\mathrm{mm}\end{array}$ & $\begin{array}{l}\text { ey } \\
\text { mm }\end{array}$ & $\lambda$ & $\delta$ & $\begin{array}{c}\mathrm{fc}_{\mathrm{c}} \\
\mathrm{MPa}\end{array}$ & $\begin{array}{c}\text { fy } \\
\mathrm{MPa}\end{array}$ & $\begin{array}{c}\mathrm{fu} \\
\mathrm{MPa}\end{array}$ \\
\hline 1 & $60 \times 60 \times 5$ & 12.00 & 0.50 & 20.83 & 30 & 30 & 0.76 & 0.71 & 51.48 & 290 & 360 \\
\hline 2 & $60 \times 60 \times 5$ & 12.00 & 0.50 & 20.83 & 30 & 30 & 0.77 & 0.70 & 54.13 & 290 & 360 \\
\hline 3 & $60 \times 60 \times 5$ & 12.00 & 0.67 & 20.83 & 40 & 40 & 0.77 & 0.69 & 56.24 & 290 & 360 \\
\hline 4 & $60 \times 60 \times 5$ & 12.00 & 0.67 & 20.83 & 40 & 40 & 0.77 & 0.69 & 58.67 & 290 & 360 \\
\hline 5 & $70 \times 70 \times 5$ & 14.00 & 0.50 & 17.86 & 35 & 35 & 0.66 & 0.67 & 51.48 & 290 & 360 \\
\hline 6 & $70 \times 70 \times 5$ & 14.00 & 0.50 & 17.86 & 35 & 35 & 0.66 & 0.66 & 54.13 & 290 & 360 \\
\hline 7 & $70 \times 70 \times 5$ & 14.00 & 0.64 & 17.86 & 45 & 45 & 0.67 & 0.65 & 56.24 & 290 & 360 \\
\hline 8 & $70 \times 70 \times 5$ & 14.00 & 0.64 & 17.86 & 45 & 45 & 0.67 & 0.64 & 58.67 & 290 & 360 \\
\hline 9 & $80 \times 80 \times 4$ & 20.00 & 0.50 & 15.63 & 40 & 40 & 0.59 & 0.57 & 51.48 & 290 & 360 \\
\hline 10 & $80 \times 80 \times 4$ & 20.00 & 0.50 & 15.63 & 40 & 40 & 0.60 & 0.56 & 54.13 & 290 & 360 \\
\hline 11 & $80 \times 80 \times 4$ & 20.00 & 0.63 & 15.63 & 50 & 50 & 0.60 & 0.55 & 56.24 & 290 & 360 \\
\hline 12 & $80 \times 80 \times 4$ & 20.00 & 0.63 & 15.63 & 50 & 50 & 0.61 & 0.54 & 58.67 & 290 & 360 \\
\hline 13 & $100 \times 100 \times 4$ & 25.00 & 0.50 & 12.50 & 50 & 50 & 0.48 & 0.51 & 51.48 & 290 & 360 \\
\hline 14 & $100 \times 100 \times 4$ & 25.00 & 0.50 & 12.50 & 50 & 50 & 0.49 & 0.49 & 54.13 & 290 & 360 \\
\hline 15 & $100 \times 100 \times 4$ & 25.00 & 0.60 & 12.50 & 60 & 60 & 0.49 & 0.48 & 56.24 & 290 & 360 \\
\hline 16 & $100 \times 100 \times 4$ & 25.00 & 0.60 & 12.50 & 60 & 60 & 0.50 & 0.47 & 58.67 & 290 & 360 \\
\hline
\end{tabular}

Table 1b. ABAQUS CFST Column Model for Parametric Study

\begin{tabular}{|c|c|c|c|c|c|c|c|c|c|c|c|}
\hline $\mathrm{S} / \mathrm{N}$ & $\begin{array}{l}\mathrm{B} \times \mathrm{D} \times \mathrm{t} \\
\mathrm{mm}\end{array}$ & $\mathrm{B} / \mathrm{t}$ & $\mathrm{e} / \mathrm{D}$ & $\mathrm{L} / \mathrm{D}$ & $\begin{array}{c}\mathrm{e}_{\mathrm{X}} \\
\mathrm{mm}\end{array}$ & $\begin{array}{l}\text { ey } \\
\mathrm{mm}\end{array}$ & $\lambda$ & $\delta$ & $\begin{array}{c}\mathrm{f}_{\mathrm{c}} \\
\mathrm{MPa}\end{array}$ & $\begin{array}{c}\text { fy } \\
\mathrm{MPa}\end{array}$ & $\begin{array}{c}\mathrm{fu} \\
\mathrm{MPa} \\
\end{array}$ \\
\hline 1 & $100 \times 100 \times 4$ & 25.00 & 0.00 & 12.50 & 0 & 0 & 0.48 & 0.51 & 50.10 & 290 & 360 \\
\hline 2 & $100 \times 100 \times 4$ & 25.00 & 0.00 & 12.50 & 0 & 0 & 0.49 & 0.50 & 52.17 & 290 & 360 \\
\hline 3 & $100 \times 100 \times 4$ & 25.00 & 0.25 & 12.50 & 25 & 25 & 0.48 & 0.51 & 50.10 & 290 & 360 \\
\hline 4 & $100 \times 100 \times 4$ & 25.00 & 0.25 & 12.50 & 25 & 25 & 0.49 & 0.50 & 52.17 & 290 & 360 \\
\hline 5 & $100 \times 100 \times 4$ & 25.00 & 0.00 & 12.50 & 0 & 0 & 0.51 & 0.56 & 50.10 & 350 & 430 \\
\hline 6 & $100 \times 100 \times 4$ & 25.00 & 0.00 & 12.50 & 0 & 0 & 0.51 & 0.55 & 52.17 & 350 & 430 \\
\hline 7 & $100 \times 100 \times 4$ & 25.00 & 0.25 & 12.50 & 25 & 25 & 0.51 & 0.56 & 50.10 & 350 & 430 \\
\hline 8 & $100 \times 100 \times 4$ & 25.00 & 0.25 & 12.50 & 25 & 25 & 0.51 & 0.55 & 52.17 & 350 & 430 \\
\hline 9 & $100 \times 100 \times 4$ & 25.00 & 0.50 & 12.50 & 50 & 50 & 0.51 & 0.55 & 51.48 & 350 & 430 \\
\hline 10 & $100 \times 100 \times 4$ & 25.00 & 0.50 & 12.50 & 50 & 50 & 0.51 & 0.54 & 54.13 & 350 & 430 \\
\hline 11 & $100 \times 100 \times 6$ & 16.67 & 0.00 & 12.50 & 0 & 0 & 0.46 & 0.63 & 50.10 & 290 & 360 \\
\hline 12 & $100 \times 100 \times 6$ & 16.67 & 0.00 & 12.50 & 0 & 0 & 0.47 & 0.62 & 52.17 & 290 & 360 \\
\hline 13 & $100 \times 100 \times 6$ & 16.67 & 0.25 & 12.50 & 25 & 25 & 0.46 & 0.63 & 50.10 & 290 & 360 \\
\hline 14 & $100 \times 100 \times 6$ & 16.67 & 0.25 & 12.50 & 25 & 25 & 0.47 & 0.62 & 52.17 & 290 & 360 \\
\hline 15 & $100 \times 100 \times 6$ & 16.67 & 0.50 & 12.50 & 50 & 50 & 0.47 & 0.62 & 51.48 & 290 & 360 \\
\hline 16 & $100 \times 100 \times 6$ & 16.67 & 0.50 & 12.50 & 50 & 50 & 0.47 & 0.61 & 54.13 & 290 & 360 \\
\hline 17 & $100 \times 100 \times 6$ & 16.67 & 0.00 & 12.50 & 0 & 0 & 0.49 & 0.67 & 50.10 & 350 & 430 \\
\hline 18 & $100 \times 100 \times 6$ & 16.67 & 0.00 & 12.50 & 0 & 0 & 0.50 & 0.66 & 52.17 & 350 & 430 \\
\hline 19 & $100 \times 100 \times 6$ & 16.67 & 0.25 & 12.50 & 25 & 25 & 0.49 & 0.67 & 50.10 & 350 & 430 \\
\hline
\end{tabular}




\begin{tabular}{|l|l|l|l|l|l|l|l|l|l|l|l|l|}
\hline 20 & $100 \times 100 \times 6$ & 16.67 & 0.25 & 12.50 & 25 & 25 & 0.50 & 0.66 & 52.17 & 350 & 430 \\
\hline 21 & $100 \times 100 \times 6$ & 16.67 & 0.50 & 12.50 & 50 & 50 & 0.49 & 0.66 & 51.48 & 350 & 430 \\
\hline 22 & $100 \times 100 \times 6$ & 16.67 & 0.50 & 12.50 & 50 & 50 & 0.50 & 0.65 & 54.13 & 350 & 430 \\
\hline
\end{tabular}

The steel contribution ratio $\delta$ and slenderness $\lambda$ were calculated based on Eurocode 4 Part 1.1 [12] as follows.

$$
\delta=\frac{A_{a} \times f_{y}}{N_{p l}}
$$

Where $A_{a}$ is the area of steel and $N_{g i}$ is the squash load of the column.

$$
\lambda=\sqrt{\frac{N_{p l}}{N_{c r}}}=\sqrt{\frac{A_{c} f_{c}+A_{a} f_{y}}{\frac{\pi^{2} E I}{L^{2}}}}
$$

Where $A_{c}$ is the area of concrete and $\mathrm{EI}=\mathrm{E}_{\mathrm{s}} \mathrm{I}_{\mathrm{S}}+0.6 \mathrm{E}_{\mathrm{cm}} ; \mathrm{I}_{\mathrm{S}}$ and $\mathrm{I}_{\mathrm{c}}$ are the second moment of inertia of the steel tube and concrete core respectively, $E_{s}$ is the modulus of elasticity of steel and $E_{\mathrm{cm}}$ is the secant modulus of elasticity of concrete.

The CFST models were classified into six sets, Sb-t-e-fy-I-P, Sb-t-e-fy-III-P and Sb-t-e-fy- V-P were modelled without using steel fibres, while a $0.75 \%$ volume of steel fiber was added to model Sb-t-e- fy -II-SF, Sb-t-e-fy-IV-SF and Sb-t-e- fy -VI-SF. The following label were used; "Sb-t- e- $f_{y}-f_{c}-p / s f$ " where " $b$ " is the columns breadth, " $t$ " is the steel tube thickness "e" is the eccentric distance of the applied axial load, " $\mathrm{f}_{\mathrm{y}}$ " is the steel yield strength, " $\mathrm{f}_{\mathrm{c}}$ " is the concrete cylindrical strength, " $\mathrm{p} / \mathrm{sf}$ " indicates whether it is a plain or steel fibre reinforced concrete infill.

\subsection{Finite Element Mesh and Geometry}

The main parameters of the model are the column breadth (B), the depth (D), the steel tube thickness ( $\mathrm{t}$ ) and the loading eccentricity (e). The plain and steel fiber CFST columns were modelled using shell and solid elements. The steel tube consisted of four-nodded quadrilateral shell element (S4R), while eight-nodded solid elements (C3D8R) with reduced integration were used for the concrete core. The loading end plate was modelled as rigid (R3D4) to enable an even stress distribution of the eccentric axial load to the column.

\subsection{Boundary Condition and Column Loading}

The column was modelled with a pin-pin end condition. A reference point was created on the loading plate to indicate the position of the ex and ey eccentric distance of the applied load.

\section{$2.4 \quad$ Material Modelling of Steel Tube}

The stress-strain curves for the steel tubes were taken from values used in the experimental tests conducted by Tokgoz and Dundar [11]. A modulus of elasticity of 200GPa and Poisson's ratio of 0.3 was employed. The yield stress and ultimate tensile strength values are also shown in Table 1(a) and (b) above.

\section{$2.5 \quad$ Modelling of Confined Concrete}

The concrete core was modelled using the concrete damaged plasticity (CDP) model available 
in the standard and explicit material library (ABAQUS [13]). The concrete damaged plasticity model uses stress-strain relationships to correlate parameters for relative concrete damage for both tension and compression under uni-axial loading as shown in Figures 2(a) and 2(b).

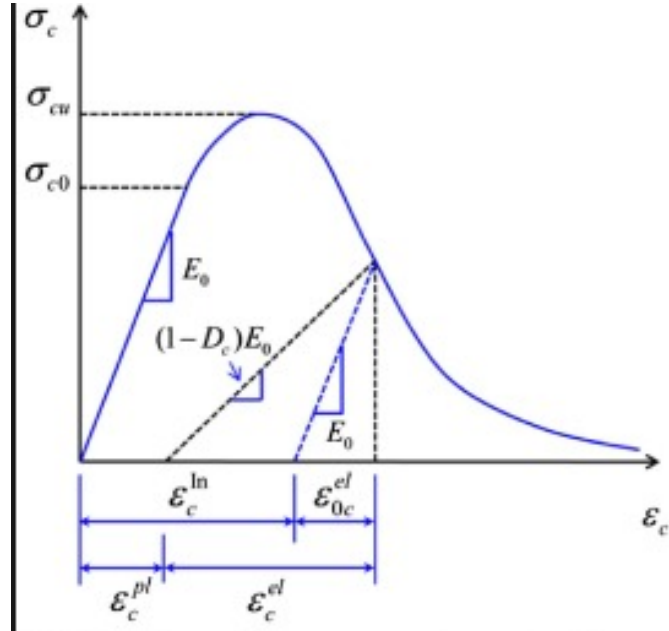

(a) Definition of the compressive material property

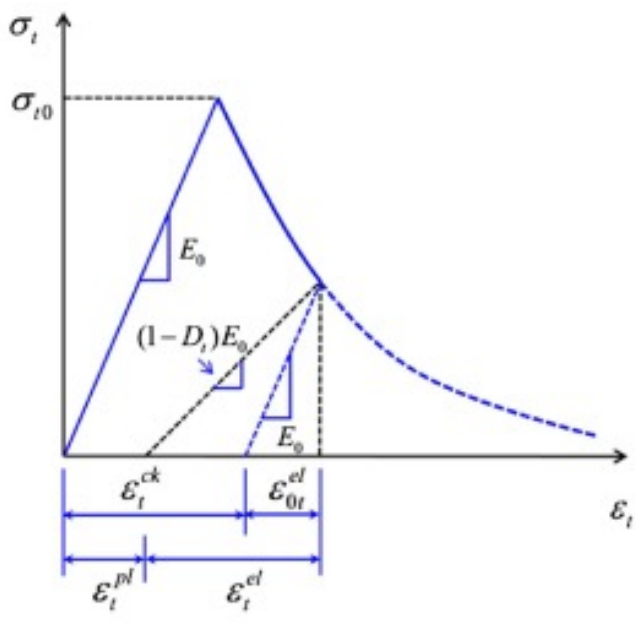

(b) Definition of the tensile material property

Figure 2. Concrete Damaged Plasticity Model

$D=\frac{E}{E_{0}}$

Where, $\mathrm{D}$ is the damage parameter of concrete in compression and tension, E0 is the initial (undamaged) elastic stiffness of the material, $\mathrm{E}$ is the damaged elastic stiffness of the confined concrete and $\mathrm{dt}$ and $\mathrm{dc}$ are the damage indices of concrete in tension and compression. Eq. 3 was used in calculating the damage parameters under uni-axial tension and compression.

The approach used to model the effects of confinement of plain and steel fiber reinforced concrete was similar to the approach used by (Dai and Lam [14]). Figure 3 shows the equivalent uniaxial representation for the stress-strain curve of confined and unconfined concrete. $f_{c}$ is the unconfined concrete cylindrical compressive strength which is equal to $0.8 \mathrm{fcu}$; where fcu is the cube compressive strength of the unconfined concrete. The unconfined strain $(\varepsilon c)$ value is taken as 0.003 for plain concrete as recommended by the ACI Specification (ACI [15]). fcc and $\varepsilon_{\mathrm{cc}}$ are the confined concrete compressive strength and confined strain, respectively. As described by Mander et al. [16].

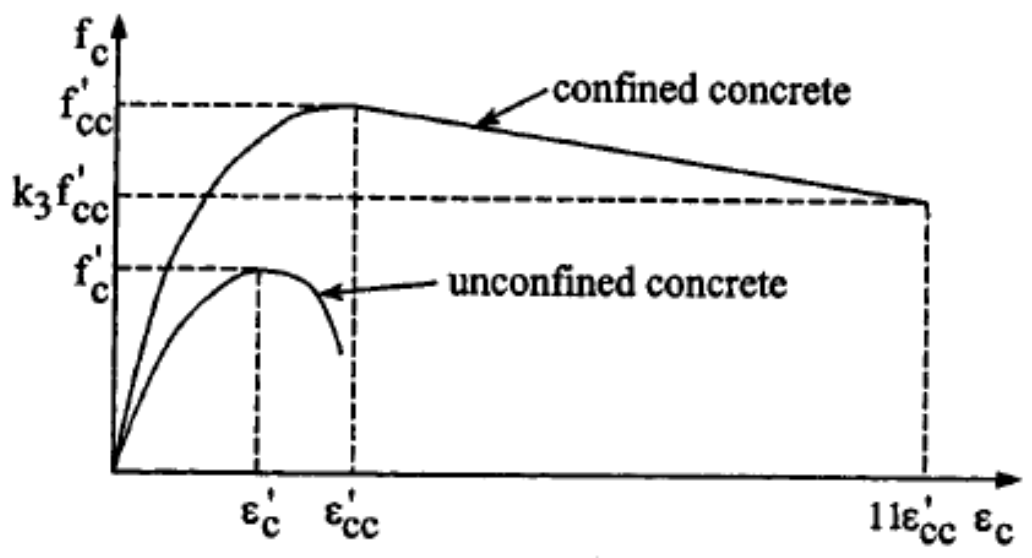

Figure 3. Confined Concrete Stress-strain Curve 


$$
\begin{aligned}
& f_{c c}=f_{c}+k_{1} f_{l} \\
& \varepsilon_{c c}=\varepsilon_{c}\left(1+k_{2} \frac{f_{l}}{f_{c}}\right)
\end{aligned}
$$

Where $f_{l}=$ lateral confining pressure from the steel tube section.

$$
f_{l}=\frac{2 \sigma \theta t}{D}
$$

Where $\sigma \theta=0.1 f_{y}$ proposed by Mander et.al. [ 16 ]

The factors $k_{1}$ and $k_{2}$ in Eqs. 4 and 5 are taken as 4.1 and 20.5 respectively, as given by Richart, Brandzaeg and Brown [17].

The equivalent stress-strain curves of unconfined and confined concrete are expressed in three parts. The first part defines the initial limit stress, which is taken as $0.5 f_{c c}$ as given by Hu et al. [18]. The Young's modulus of confined concrete is calculated using the empirical formula provided in the ACI code [15], given in Eq. 7.

$$
E_{c c}=4700 \sqrt{f_{c c}} M p a
$$

Where $f_{c c}$ is the strength of confined concrete. The Poisson's ratio of confined concrete is taken as 0.2 as given in EN 1992-1-1 [19]. The second part defines the nonlinear portion of the stress-strain curve starting from the proportional limit stress $0.5 f_{c c}$ to the confined strength of the concrete $f_{c c}$. This part of the curve was proposed by Saenz [20] and can be determined from Eq. 8.

$$
\begin{aligned}
& f=\frac{E_{c} \varepsilon_{c}}{1+\left(R+R_{E}-2\right)\left(\frac{\varepsilon}{\varepsilon_{c c}}\right)-(2 R-1)\left(\frac{\varepsilon}{\varepsilon_{c c}}\right)^{2}+R\left(\frac{\varepsilon}{\varepsilon_{c c}}\right)^{2}} \\
& R_{E}=\frac{E_{c c} \varepsilon_{c c}}{f_{c c}} \\
& R=\frac{R_{E}\left(R_{\sigma}-1\right)}{\left(R_{\sigma}-1\right)^{2}}-\frac{1}{R_{\varepsilon}}
\end{aligned}
$$

Where the constants $\mathrm{R} \sigma$ and $\mathrm{R} \varepsilon$ are equal to 4 as recommended by $\mathrm{Hu}$ and Schnobrich [21].

The third part defines the descending value of the confined concrete stress-strain curve; this part starts from the maximum confined concrete strength $\mathrm{f}_{\mathrm{cc}}$ to a lower value $\mathrm{rk}_{3 \mathrm{c}} \mathrm{f}_{\mathrm{cc}}$ with a corresponding strain value of $11 \varepsilon_{\mathrm{cc}}$ as proposed by $\mathrm{Hu}$ et al. [18]. 


\subsection{Material Modelling of Steel Fiber}

The steel fiber dosage used in the model was a $0.75 \%$ volume $\left(58.88 \mathrm{~kg} / \mathrm{m}^{3}\right)$ as described in the experimental tests. Table 2 shows the material geometry of the steel fiber is given in Musmar [22], Eq. 11 to determine the value of the tensile strength of the concrete.

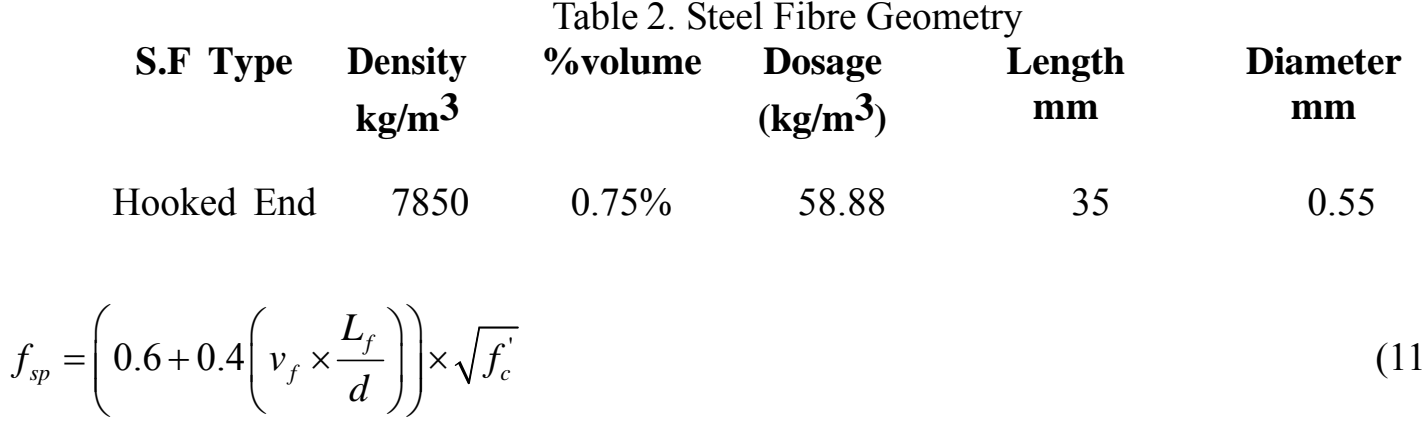

Where $\mathrm{f}_{\mathrm{sp}}$ is the concrete tensile strength in $\mathrm{MPa}, v_{f}$ is the fiber volume, $\mathrm{Lf}=$ length of fiber, $\mathrm{d}=$ diameter of fiber and $f_{c}$ is the compressive strength of concrete.

\subsection{Concrete - Steel Tube Interface}

Contact between the steel and concrete were modelled as a general contact. Friction between the two faces is maintained throughout when in contact. After conducting a parametric study for the coefficient of friction, 0.2 was chosen as it gave the best match for friction between the steel tube and concrete surfaces.

\section{RESULTS AND DISCUSSION}

The ultimate axial load and moment values for each column were reported in Table 3 . Figure 4 shows the graphical plot of force vs B/t ratio, while Figure 5 shows graphical plot of moment vs $\mathrm{B} / \mathrm{t}$ ratio for plain and steel fibre reinforced concrete infill for the CFST columns. It can be seen that the use of steel fibre reinforced concrete infill had little effect on the ultimate strength of the column. The steel tube thickness and load eccentricity are important factor which governed the ductility and ultimate strength of the columns.

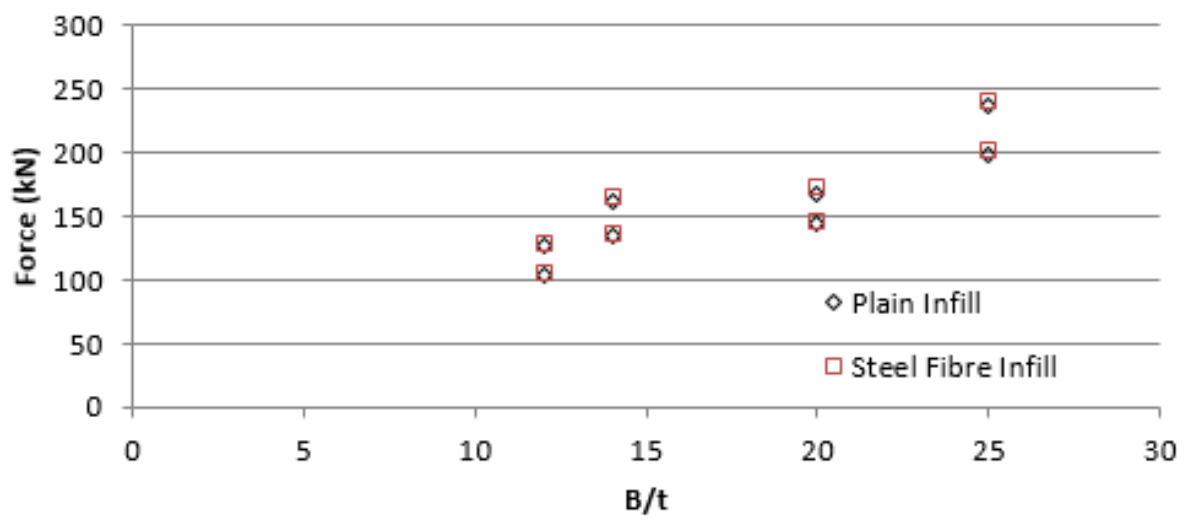

Figure 4. Force vs B/t Ratio 


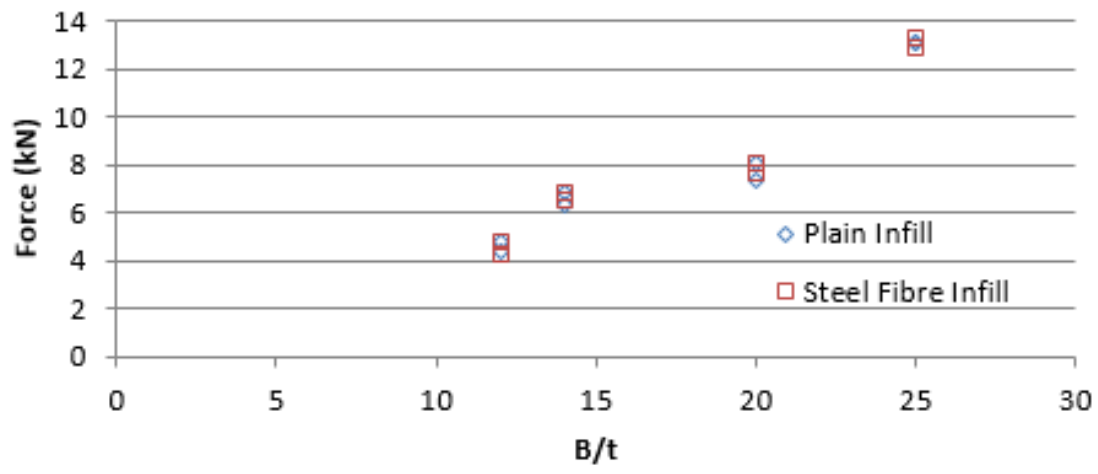

Figure 5. Moment vs B/t Ratio

Table 3. Finite Element Analysis Result

$\begin{array}{crrcc}\text { Model No. } & \text { Pp }(\mathrm{kN}) & \text { PSF }(\mathrm{kN}) & \begin{array}{c}\text { MP } \\ (\mathrm{kN} . \mathrm{m})\end{array} & \begin{array}{c}\text { MSF } \\ (\mathrm{kN} . \mathrm{m})\end{array} \\ \text { S60-5-30-290 } & 126.6 & 128.1 & 4.36 & 4.3 \\ \text { S60-5-40-290 } & 104.7 & 105.8 & 4.78 & 4.83 \\ \text { S70-5-35-290 } & 161.3 & 164.8 & 6.31 & 6.57 \\ \text { S70-5-45-290 } & 134.4 & 137.2 & 6.86 & 6.89 \\ \text { S80-4-40-290 } & 167.8 & 173.8 & 7.39 & 7.72 \\ \text { S80-4-50-290 } & 144.6 & 146.3 & 8.04 & 8.04 \\ \text { S100-4-50-290 } & 237.5 & 239.9 & 13.06 & 12.88 \\ \text { S100-4-60-290 } & 198.2 & 201.6 & 13.15 & 13.27\end{array}$

\section{PARAMETRIC STUDY}

Prior to a sensitivity analysis, The FEA results were validated with the laboratory experiments which is discussed extensively in the next section. The parameters investigated includes; the steel tube thickness, concrete compressive strength, e/D ratio and steel tube yield strength. Table 4 shows the result obtained from the parametric study.

Table 4. CFST Parametric Study

$\begin{array}{ccccc}\text { Model No. } & \text { PP }(\mathrm{kN}) & \text { PSF }(\mathrm{kN}) & \begin{array}{c}\text { fy } \\ (\mathrm{MPa})\end{array} & \mathrm{B} / \mathrm{t} \\ \text { S100-4-0-290 } & 826.9 & 867.3 & 290 & 25 \\ \text { S100-6-0-290 } & 1006 & 1038.17 & 290 & 16.67 \\ \text { S100-4-0-350 } & 927.3 & 963.6 & 350 & 25 \\ \text { S100-6-0-350 } & 1147 & 1182 & 350 & 16.67 \\ \text { S100-4-25-290 } & 364.6 & 401.3 & 290 & 25 \\ \text { S100-6-25-290 } & 468 & 517.13 & 290 & 16.67 \\ \text { S100-4-25-350 } & 408 & 449.1 & 350 & 25 \\ \text { S100-6-25-350 } & 524.7 & 577.5 & 350 & 16.67 \\ \text { S100-4-50-290 } & 237.5 & 239.9 & 290 & 25 \\ \text { S100-6-50-290 } & 311.2 & 317 & 290 & 16.67 \\ \text { S100-4-50-350 } & 269.8 & 276.7 & 350 & 25 \\ \text { S100-6-50-350 } & 354.9 & 353.8 & 350 & 16.67\end{array}$




\subsection{Steel Tube Thickness}

For an increase in steel tube thickness from $4 \mathrm{~mm}$ to $6 \mathrm{~mm}$ there was a $21 \%$ increase in ultimate strength for columns loaded under compression only. For columns loaded with combined compression and bending, the increase recorded was about $32 \%$. Figure 6 shows the steel tube thickness has a significant effect on the ductility of the columns. For columns having a depth over thickness $(\mathrm{D} / \mathrm{t})$ ratio greater than 18 and eccentricity over depth $(\mathrm{e} / \mathrm{D})$ ratio greater than 0.5 , there was an uneven stress distribution during the early stages of load application which resulted in a premature plastic deformation at the top of the steel tube perpendicular to the eccentric load direction.

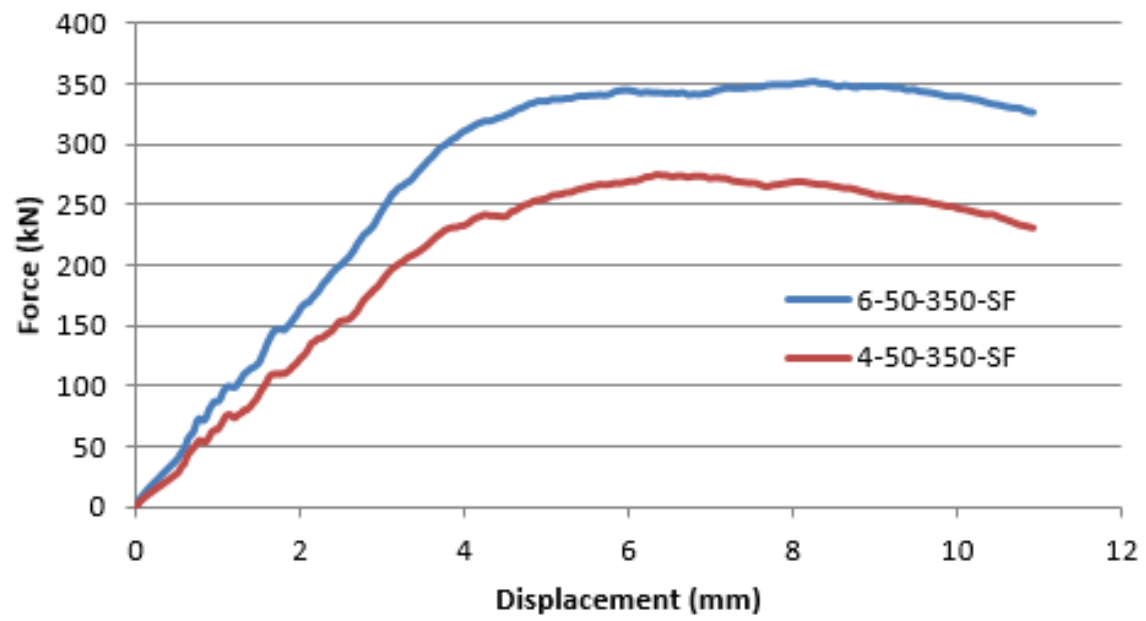

Figure 6. Steel Tube Thickness Effectiveness

\subsection{Concrete Compressive Strength}

The concrete compressive strength had little effect on the ultimate strength value recorded for each column due to the slenderness of the column. Figures 7 (a) and 7(b) shows columns filled with steel fibre reinforced concrete (SFRC) and plain concrete. The SFRC columns maintained its ultimate strength value for a longer time period and therefore, gave the column a better ductility. For columns filled with plain concrete, there was a sudden drop in the strength of the columns. Figures 8(a) and 8(b) shows columns subjected to combine bending and compression, it was observed that columns filled with steel fibre reinforced concrete maintained $85 \%$ of its axial strength while the displacement increased.

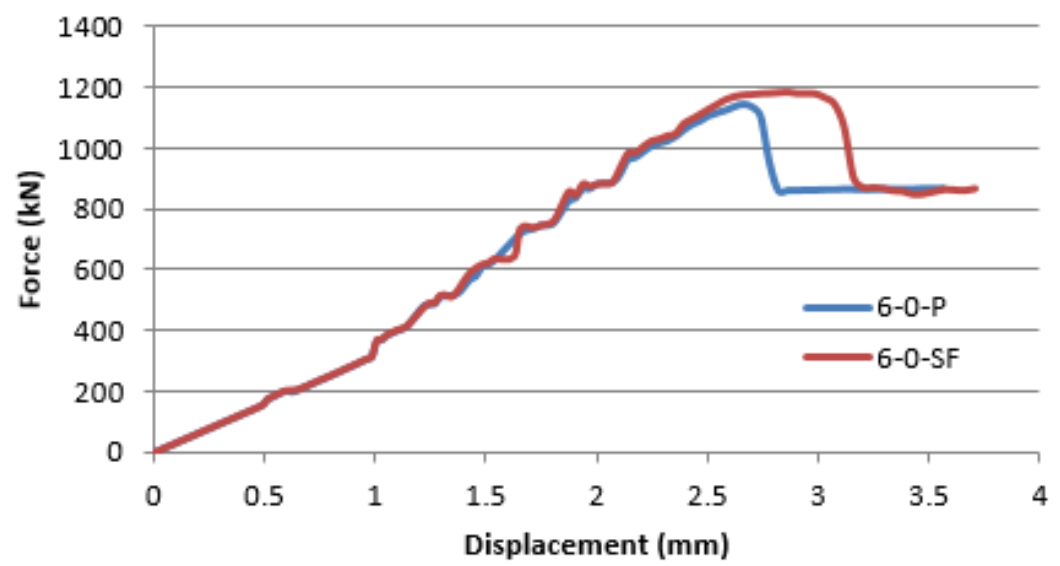

(a) $6 \mathrm{~mm}$ steel tube thickness 


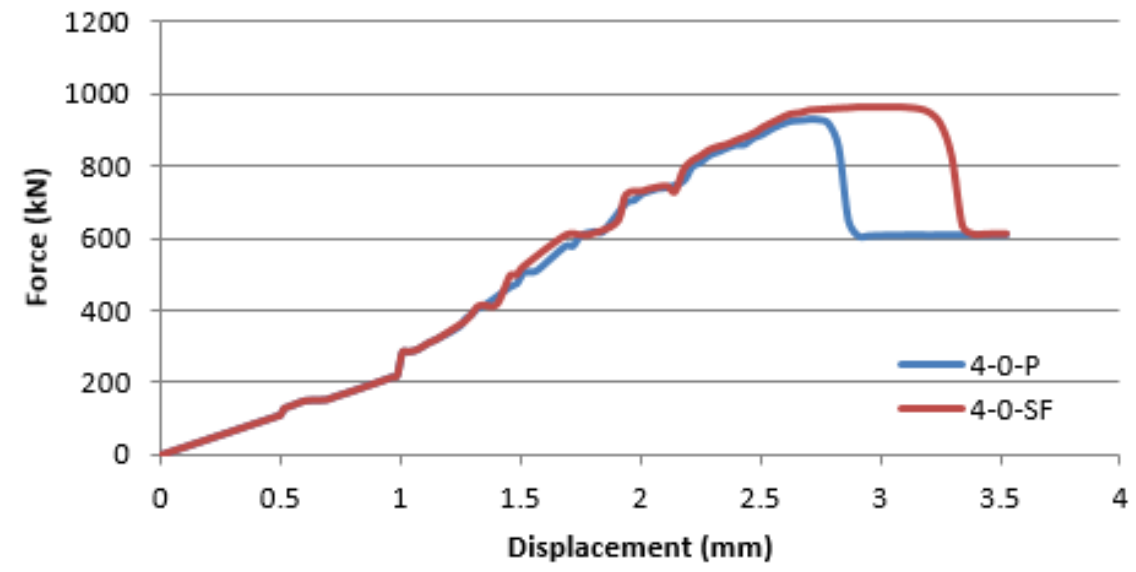

(b) $4 \mathrm{~mm}$ steel tube thickness

Figure 7. Effectiveness of Concrete Compressive Strength under Compression Only

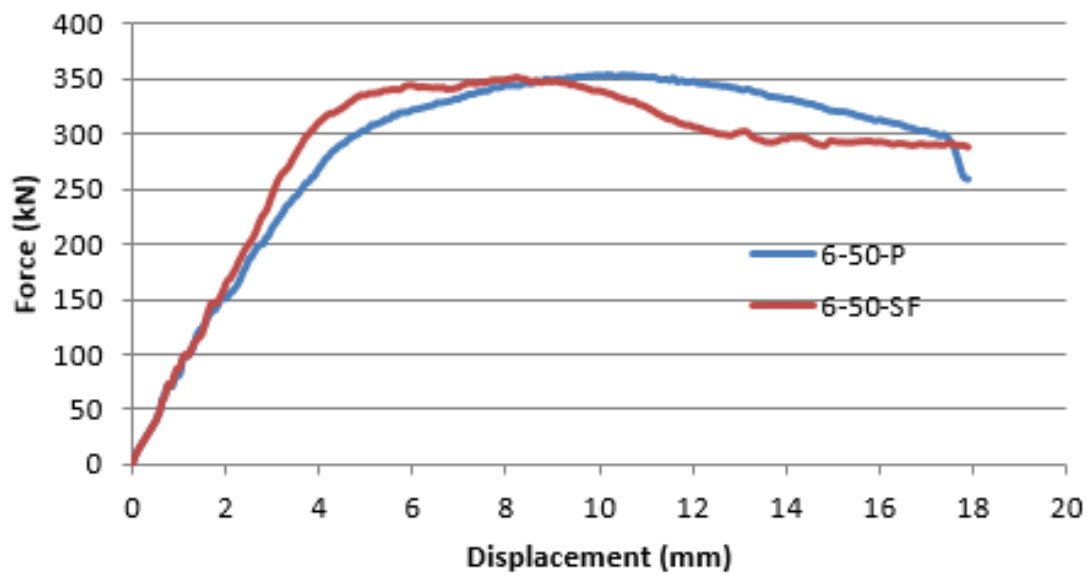

(a) $6 \mathrm{~mm}$ steel tube thickness

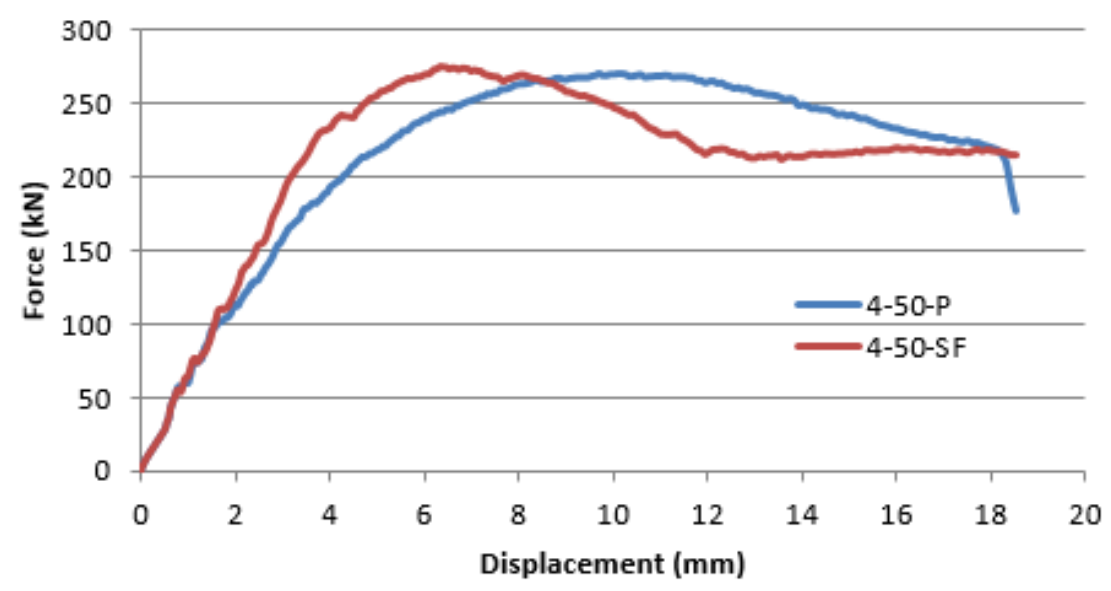

(b) $4 \mathrm{~mm}$ steel tube thickness

Figure 8. Effectiveness of Concrete Compressive Strength under Combine Bending and Compression 


\subsection{Load Eccentricity}

The e/D ratio of the column was a contributing factor to the ultimate strength and moment values recorded. Figure 9 (a) shows for a $10 \mathrm{~mm}$ increase in eccentric load distance of the columns, there was an average of $20 \%$ decrease in the ultimate strength value recorded for all CFST columns, however, the moment values recorded were not significantly affected. Figure 9 (b) shows there was an average of $6 \%$ increase in moment value recorded, with a $10 \mathrm{~mm}$ increase in the eccentric load distance of the applied axial load.

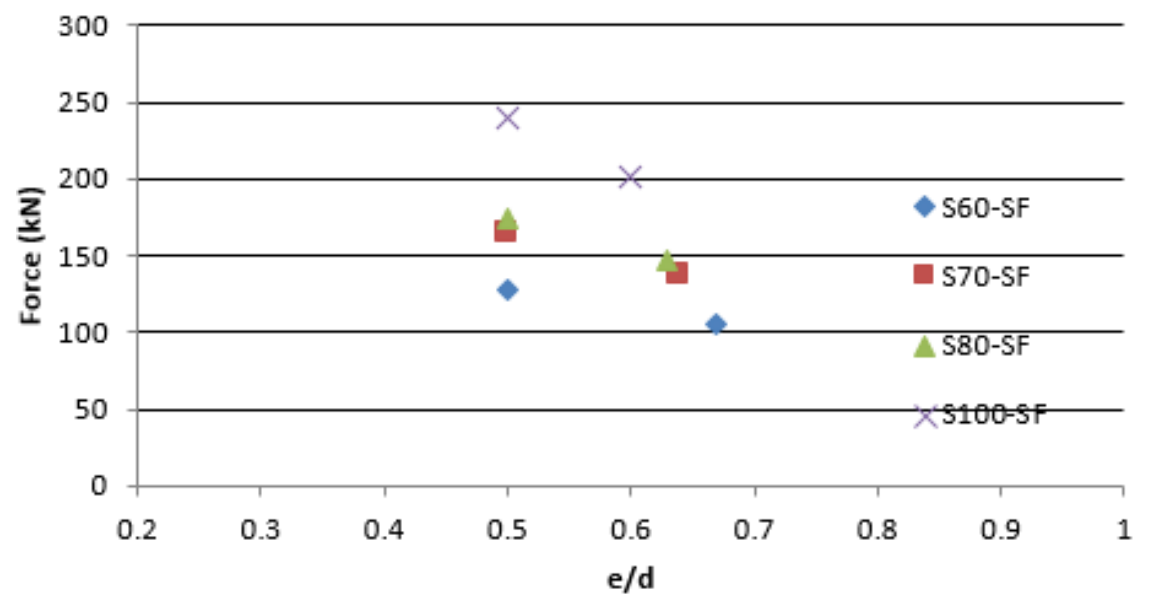

(a) Force Vs e/D ratio

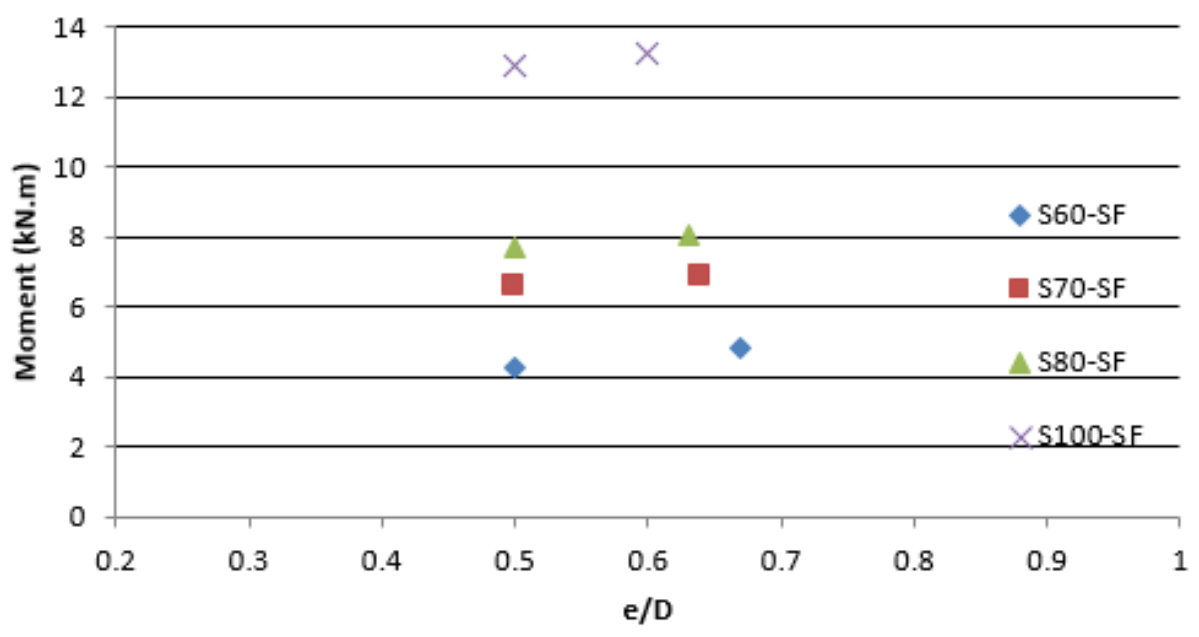

b) Moment Vs e/D ratio

Figure 9. Effectiveness of e/D Ratio of the Column

\subsection{Steel Tube Yield Strength}

The steel tube yield strength contributed significantly to the ultimate axial strength, but did not affect the ductility of the column. For a $20 \%$ increase in the steel tube yield strength there was a corresponding $14 \%$ increase in the axial strength of the column. Figure 10 shows the load deflection curve comparison of columns having similar geometries, but different steel tube yield strength. 


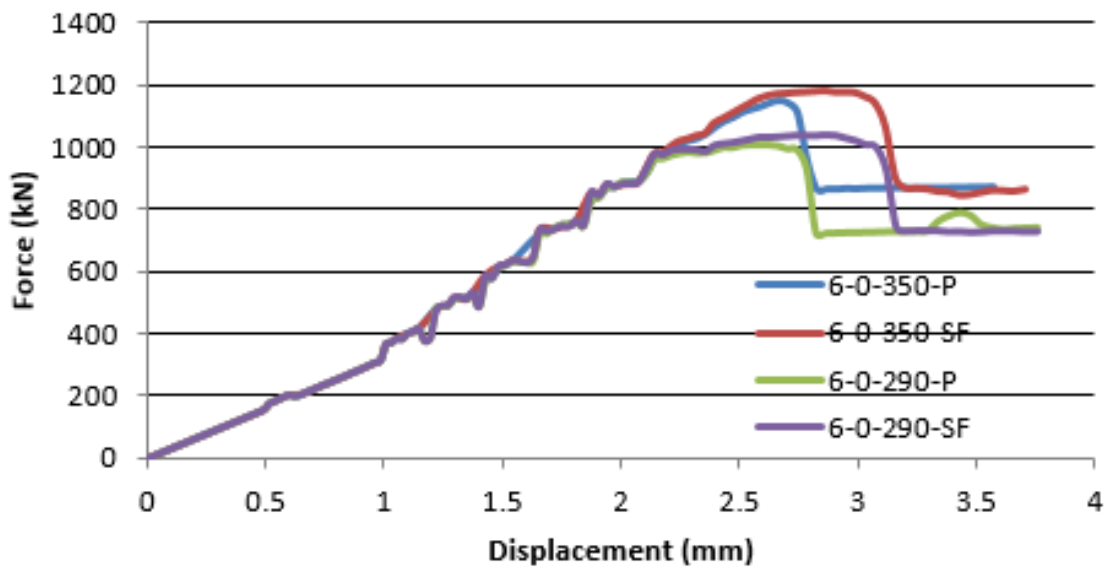

Figure 10. Steel Tube Yield Strength Effectiveness

\subsection{Concrete Infill Type}

The addition of steel fibre to the concrete increases the tensile strength of the concrete and also controls the crack width propagation of the column. For columns filled with steel fibre reinforced concrete, the tensile damage of the concrete was relatively low compared to columns filled with plain concrete and this affected the crack propagation and ductility of the column. Figures 11(a) and (b) shows the concrete tensile damage for S60-5-30-290-I-P and S60-5-30-290-II-SF respectively, when a load of $100 \mathrm{kN}$ was applied to the column.

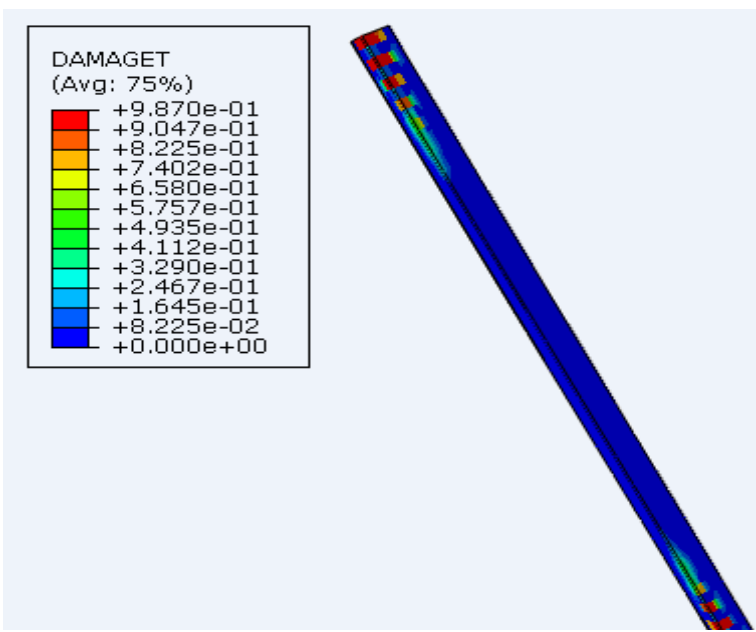

(a) Tensile damage of plain Concrete at $100 \mathrm{kN}$

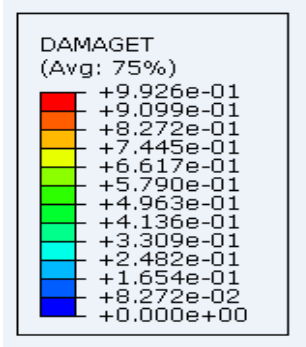

(b) Tensile damage of SFR concrete at $100 \mathrm{kN}$

Figure 11. Effectiveness of Concrete Infill

\section{COMPARISON OF FINITE ELEMENT ANALYSIS WITH LABORATORY EXPERIMENT AND EUROCODE 4 DESIGN GUIDE}

There was good correlation between recorded values obtained from the numerical analysis when compared to the experimental and Eurocode 4 values. The axial compressive strength known as the squash load of a tubular column is calculated by adding the strength of its members as given in Eurocode 4 Part 1-1. A further calculation needs to be carried out when the column is loaded under combined compression and bending. The ultimate axial strength obtained from the finite element 
(PFEA) analysis, laboratory experiments (PEXP) and Eurocode 4 calculations (PEC4) are reported in Table 5. The squash load for a fully encased concrete filled steel tube column according to Eurocode 4 is calculated using Eq. 12. Figures 12(a) and (b) shows the plot of force vs moment, while Figures 13 (a) to (d) shows the load deflection curve comparison for the laboratory experiments and FEA.

$$
P_{E C 4}=A_{a} f_{y}+A_{c} f_{c}
$$

Where $f_{y}$ is the yield strength of the structural steel, $f_{o}$ is the cylindrical compressive strength of concrete. $A_{a}$ and $A_{c}$ are the area of steel and concrete respectively.

The moment $(\mathrm{M})$ of the column at mid-height was calculated using the equation $M=E \times\left(+d_{\mathrm{m}}\right)$ where $\mathrm{P}$ is the ultimate load, $\mathrm{e}$ is the eccentric distance and $\mathrm{d}_{\mathrm{m}}$ is the deflection of the column at mid-height.

Table 5. Finite Element Analysis, Laboratory Experiments and Eurocode 4 Comparison

\begin{tabular}{|c|c|c|c|c|c|c|c|c|c|c|}
\hline el. & $\begin{array}{c}\mathrm{P}_{\mathrm{FEA}} \\
\mathrm{kN}\end{array}$ & $\begin{array}{c}P_{\text {EXP }} \\
\mathrm{kN}\end{array}$ & $\begin{array}{c}\mathrm{P}_{\mathrm{EC} 4} \\
\mathrm{kN}\end{array}$ & $\begin{array}{l}\mathrm{M}_{\mathrm{FEA}} \\
\mathrm{kN} . \mathrm{m}\end{array}$ & $\begin{array}{l}\mathrm{M}_{\mathrm{EXP}} \\
\mathrm{kN} . \mathrm{m}\end{array}$ & $\begin{array}{l}\mathrm{M}_{\mathrm{EC} 4} \\
\mathrm{kN} . \mathrm{m}\end{array}$ & $\frac{\mathrm{P}_{\mathrm{EXP}}}{\mathrm{P}_{F E A}}$ & $\frac{\mathrm{P}_{\mathrm{EC} 4}}{\mathrm{P}_{F E A}}$ & $\frac{M_{\mathrm{EXP}}}{M_{\text {FEA }}}$ & $-\frac{M_{\mathrm{E}}}{M_{F}}$ \\
\hline 290-I-P & 26.6 & 128 & 127.6 & 4.36 & 4.48 & 3.83 & 1.01 & 1.01 & 1.03 & \\
\hline S60 & 81 & 124 & .7 & 3 & 4.5 & 89 & 97 & 1.01 & 1.05 & \\
\hline S60 & 4 & 97 & 10.3 & 4.78 & 4.6 & 4.42 & 0.93 & 1.05 & 0.96 & \\
\hline S60- & 105.8 & 104 & 112 & 4.83 & 4.63 & 4.48 & 0.98 & 1.06 & 0.96 & \\
\hline $\mathrm{S} 7 \mathrm{C}$ & 3 & 168 & .6 & & & & 04 & 1.01 & 1.02 & \\
\hline S70- & 164.8 & 174 & 165.7 & 6.57 & 6.46 & 5.80 & 1.06 & 1.01 & 0.98 & \\
\hline S70 & 134.4 & 142 & 144.8 & & 6.61 & 6.52 & 1.06 & 1.08 & 0.96 & \\
\hline S70- & 137.2 & 148 & 147.1 & & 6.65 & 6.62 & 1.08 & 1.07 & 0.97 & \\
\hline $\mathrm{S} 80$ & 167.8 & 173 & 184.5 & 7.39 & 7.65 & 7.38 & 1.03 & 1.10 & 1.04 & \\
\hline S80- & 173.8 & 175 & 189 & 7.72 & 7.9 & 7.56 & 01 & 1.09 & 1.02 & \\
\hline S80 & 144.6 & 147 & 158.8 & & 7.87 & 7.94 & 1.02 & 1.10 & 0.98 & 0 . \\
\hline S80- & 146.3 & 156 & 16 & & 7.92 & 8.02 & 1.07 & 1.10 & 0.99 & \\
\hline $\mathrm{S} 10$ & 237.5 & 245 & 255.2 & 06 & 12.99 & 12.76 & 1.03 & 1.07 & 0.99 & \\
\hline S100-4-5 & 239.9 & 248 & 258.9 & 12.88 & 13.13 & 12.95 & 1.03 & 1.08 & 1.02 & \\
\hline S100-4-6 & 198.2 & 218 & 225.6 & 13.15 & 13.33 & 13.53 & 1.10 & 1.14 & 1.01 & \\
\hline S100-4-60-290-IV-SF & 201.6 & 222 & 227.2 & 13.27 & 13.44 & 13.63 & 1.10 & 1.13 & 1.01 & 1. \\
\hline & & & & & & & 1.0 & 1.07 & 1.00 & \\
\hline Standard Deviation & & & & & & & 0.05 & 0.04 & 0.03 & \\
\hline
\end{tabular}




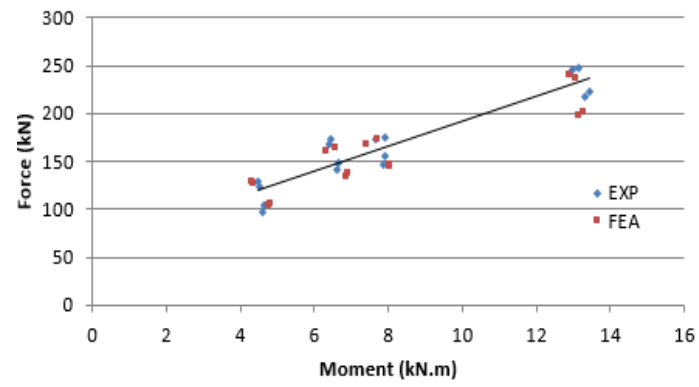

(a) Comparison of FEA with experiment

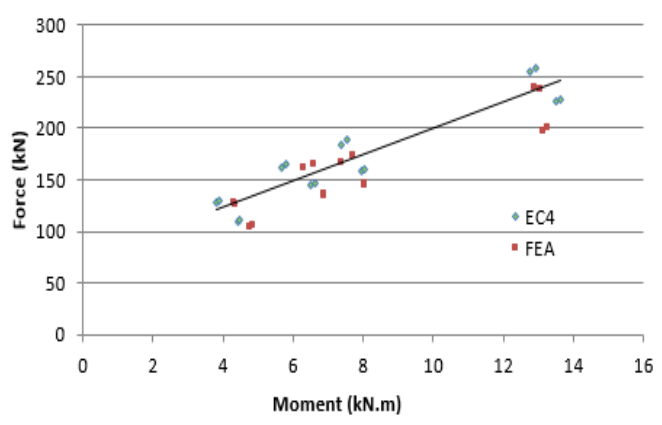

(b) Comparison of FEA with Eurocode 4



(a) Force vs Displacement

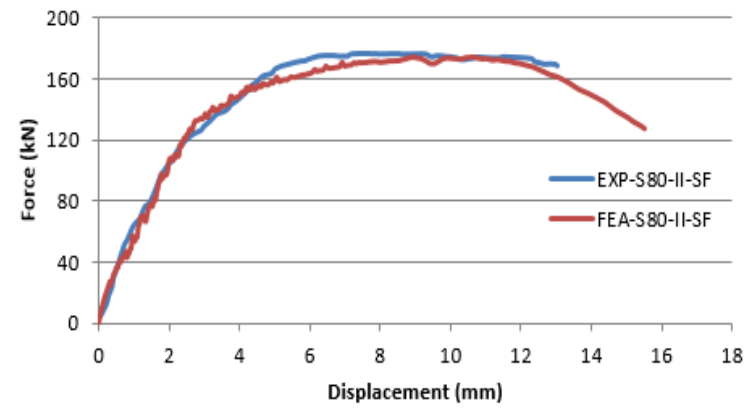

(c) Force vs Displacement

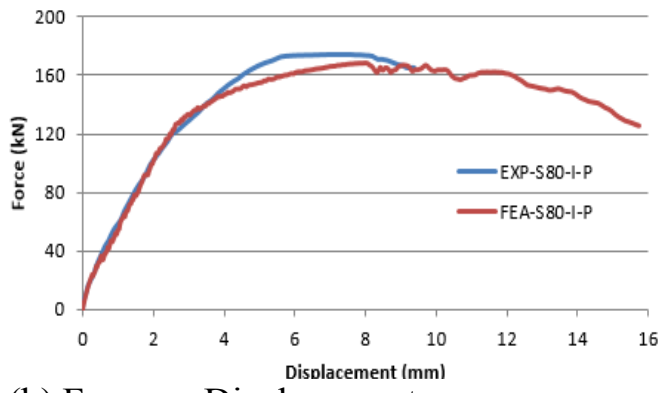

(b) Force vs Displacement

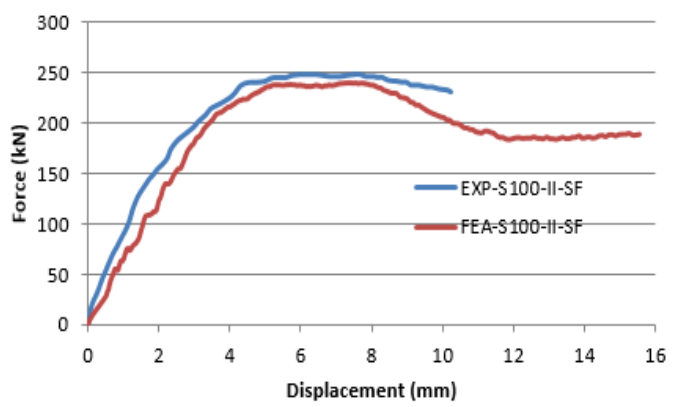

(d) Force vs Displacement

Figure 13. Force vs Displacement Curve FEA and Laboratory Experiment Comparison

\section{CONCLUSIONS}

The computational finite element modelling of concrete filled steel tubular column with plain and steel fiber reinforced concrete infill is presented in this study. There was a good agreement between ultimate strength and moment values of the columns when compared to values obtained from experimental data and Eurocode 4 Part 1-1. 
Addition of steel fiber to the concrete had little effect on the ultimate strength of the column. However, this affected the ductility and crack width propagation of the column and also increased the concrete tensile strength. This indicates that for CFST columns filled with steel fiber reinforced concrete, the column will have a higher ductility when compared to using a plain concrete infill. The steel tube yield strength had an effect on the ultimate axial strength of the column; however, it did not contribute to the ductility of the column. It is recommended to increase the steel tube thickness rather than using a steel tube section with a higher yield strength for design purposes. Using an e/D ratio less than 0.5 for the construction of slender columns is recommended so as to utilize the full section of the column when loaded axially.

\section{ACKNOWLEDGEMENTS}

The authors wish to express gratitude to the Heavy Engineering Educational \& Research Foundation (HEERF) for their scholarship support. The authors also acknowledge the contribution of NeSI high-performance computing facilities to the results of this research. NZ's national facilities are provided by the NZ eScience Infrastructure and funded jointly by NeSI's collaborator institutions and through the Ministry of Business, Innovation \& Employment's Research Infrastructure programme.

\section{REFERENCES}

[1] Han, L, Zhao, X. and Lu, H., "Concrete-filled Tubular Members and Connections", CRC Press. 2014.

[2] Kitada, T., "Ultimate Strength and Ductility of State-of-the-art Concrete-filled Steel Bridge Piers in Japan", Eng. Struct., 1998, Vol. 20, No. 4-6, pp. 347-54.

[3] Brauns, J., "Analysis of Stress State in Concrete-filled Steel Column", Journal of Constructional Steel Research ", 1999, Vol. 49, No. 2, pp.189-96.

[4] Ellobody, E., Young, B. and Lam, D., "Behaviour of Normal and High Strength Concrete-filled Compact Steel Tube Circular Stub Columns", Journal of Constructional Steel Research, 2006, Vol. 62, No. 7, pp. 706-15.

[5] Ellobody, E., "Numerical Modelling of Fibre Reinforced Concrete-filled Stainless Steel Tubular Columns", Thin-Walled Structures, 2013, Vol. 63, pp. 1-12.

[6] Zhao, Lok, Li, and Lim, "Behavior of Steel Fiber Reinforced Concrete under Dynamic Load, Proc., 4th Asia-Pacific Conf. on Shock and Impact Loads on Structures: CI-Premier, Singapore, 2001.

[7] Zeghiche, J. and Chaoui, K., "An Experimental Behaviour of Concrete-filled Steel Tubular Columns", Journal of Constructional Steel Research, 2005, Vol. 61, No. 1, pp. 53-66.

[8] Johansson, M. and Gylltoft, K., "Structural Bhavior of Slender Circular Steel-concrete Composite Columns under Various Means of Load Application", Steel and Composite Structures 2001, Vol. 1, No. 4, pp. 393-410.

[9] Eltobgy, H.H., "Structural Design of Steel Fibre Reinforced Concrete in-filled Steel Circular Columns", Steel and Composite Structures, 2013, Vol. 14, No. 3, pp. 267-82.

[10] Gopal, S.R. and Manoharan, P.D., "Experimental Behaviour of Eccentrically Loaded Slender Circular Hollow Steel Columns in-filled with Fibre Reinforced Concrete", Journal of Constructional Steel Research, 2006, Vol. 62, No. 5, pp. 513-20.

[11] Tokgoz, S. and Dundar, C., "Experimental Study on Steel Tubular Columns in-filled with Plain and Steel Fiber Reinforced Concrete", Thin-Walled Structures, 2010, Vol. 48, No. 6, pp.414-22. 
[12] CEN. EN 1994-1-1, Eurocode 4: Design of Composite Steel and Concrete Structures-Part 1-1: General Rules and Rules for Buildings, Comité Européen de Normalisation 2005.

[13] Simulia, D. ABAQUS 6.13 User's Manual. Dassault Systems, Providence, RI 2013.

[14] Dai, X. and Lam, D., "Numerical Modelling of the Axial Compressive Behaviour of Short Concrete-filled Elliptical Steel Columns", Journal of Constructional Steel Research, 2010, Vol. 66, No. 7, pp. 931-42.

[15] ACI B. 318-Building Code Requirements for Reinforced Concrete and Commentary, American Concrete Institute International 1999.

[16] Mander, J.B., Priestley, M.J. and Park, R., "Theoretical Stress-strain Model for Confined Concrete", J. Struct. Eng., 1988, Vol. 114, No. 8, pp. 1804-26.

[17] Richart, F.E., Brandtzaeg, A. and Brown, R.L., "A Study of the Failure of Concrete under Combined Compressive Stresses, 1928.

[18] Hu, H., Huang, C., Wu, M., Wu, Y., "Nonlinear Analysis of Axially Loaded Concrete-filled Tube Columns with Confinement Effect", J. Struct. Eng., 2003, Vol. 129, No. 10, pp. 1322-9.

[19] CEN E. Eurocode 2: Design of Concrete Structures, European Committee for Standardization, 1992.

[20] Saenz, LP., "Equation for the Stress-strain Curve of Concrete", ACIJour. 1964, Vol. 61, No. 9, pp. 1229-35.

[21] Hu, H. and Schnobrich, W.C., "Constitutive Modeling of Concrete by Using Nonassociated Plasticity", J. Mater. Civ. Eng., 1989, Vol. 1, No. 4, pp. 199-216.

[22] Musmar, M., "Tensile Strength of Steel Fiber Reinforced Concrete", Contemporary Engineering Sciences, 2013, Vol. 6, No. 5, pp. 225-37. 